\title{
Influence of autologous dendritic cells on cytokine-induced killer cell proliferation, cell phenotype and antitumor activity in vitro
}

\author{
JINGSONG CAO ${ }^{1}, \mathrm{CONG} \mathrm{CHEN}^{2}, \mathrm{YUHUAN} \mathrm{WANG}^{1}, \mathrm{XUECHENG} \mathrm{CHEN}^{3}, \mathrm{ZEYING} \mathrm{CHEN}^{4}$ and XIAOLING LUO ${ }^{1}$ \\ ${ }^{1}$ Shenzhen Hornetcorn Biotechnology Co. Ltd, Shenzhen, Guangdong 518045; ${ }^{2}$ Laboratory Department, \\ The Second Affliated Hospital of Nanhua University; ${ }^{3} \mathrm{MCH}$ Hospital of Zhuhui, Hengyang, \\ Hunan 421001; ${ }^{4}$ Changsha Medical University, Changsha, Hunan 410219, P.R. China
}

Received May 2, 2015; Accepted May 26, 2016

DOI: $10.3892 / \mathrm{ol} .2016 .4839$

\begin{abstract}
Dendritic cell (DCs) are essential antigen processing and presentation cells that play a key role in the immune response. In this study, DCs were co-cultured with cytokine-induced killer cells (DC-CIKs) in vitro to detect changes in cell proliferation, cell phenotype and cell cytotoxicity. The results revealed that the DCs were suitable for co-culture with CIKs at day 7, and that cell quantity of DC-CIKs was lower than that of CIKs until day 11, but it was significantly improved to 1.17 -fold that of CIKs at day 13 . Flow cytometry was used to detect the cell phenotype of CIKs and DC-CIKs. Compared with CIKs at day 13, the percentage of $\mathrm{CD}^{+}, \mathrm{CD}^{+} \mathrm{CD}^{+}, \mathrm{CD}^{+} \mathrm{CD}^{+}$and $\mathrm{CD}^{+} \mathrm{CD}^{+} 6^{+}$ $\mathrm{T}$ cells in DC-CIKs was significantly improved 1.02, 1.79, 1.26 and 2.44-fold, respectively. In addition, trypan blue staining analysis demonstrated that the cell viability of CIKs and DC-CIKs was $96 \%$ and $98 \%$, respectively. Furthermore, 3-(4,5-dimethylthiazol-2-yl)-2,5-diphenyltetrazolium bromide (MTT) analysis verified that CIK and DC-CIK cytotoxicity in Hela cells was $58 \%$ and $80 \%$, respectively, with a significant difference. Taken together, our results indicate that the cell proliferation, cell phenotype and antitumor activity of CIKs were all enhanced following co-culture with DCs in vitro. These results are likely to be useful for DC-CIK application in antitumor therapies.
\end{abstract}

\section{Introduction}

Cellular immunotherapy is a novel treatment for tumors following chemotherapy and hematopoietic stem cell transplantation (1). It aims to stimulate the immune system of patients to triggered an anti-tumor immune response, eventually enhancing the body's natural abilities to recognize and

Correspondence to: Mrs. Xiaoling Luo, Shenzhen Hornetcorn Biotechnology Co. Ltd, 14 Shihua Road, Shenzhen, Guangdong 518045, P.R. China

E-mail: luoxiaoling@hornetcorn.com

Key words: dendritic cells, cytokine-induced killer cells, flow cytometry, MTT kill cancer cells (2). Additional research found that cellular immunotherapy based in different immune cells had various anti-tumor efficacy (3). Among the numerous types of immune cells, dendritic cells (DCs) and cytokine-induced killer cells (CIKs) are extensively used in the clinic $(2,4,5)$; the former are highly specialized antigen-presenting cells (APC) (6) and the latter have a broad spectrum in the killing of tumor cells (7).

Clinical studies have demonstrated that specifically designed DC-targeted cancer cell vaccines have different clinical benefits (8-10). Frank et al demonstrated that patients who received dendritic cell vaccines generated by the adherence method demonstrated increased $\mathrm{T}$ cell proliferation in response to the vaccination (11). Zhu et al noted that DC vaccines and CIK therapy could induce an immune response against advanced colorectal cancer, thereby improving quality of life and prolonging overall survival (12). A large clinical study demonstrated that the antitumor response of CIKs could be influenced by DCs in vivo $(1,4,12)$, but the influence of DCs on CIKs cultured in vitro was unclear.

In this study, data analysis revealed that the highest amplification fold of CIKs occurred on day 7. Further study revealed that the DC-CIK cell quantity, partial cell phenotype and cell cytotoxicity were significantly upregulated compared with CIKs. The results are likely to be useful for DC-CIK application and development in antitumor therapies.

\section{Materials and methods}

Ethics and consent. Peripheral blood was donated from volunteers after receiving informed consent, and the study was approved by the ethics committee of the Second Affiliated Hospital of Nanhua University, Henyang, China.

CIK culture. Lymphocytes were separated and cultured in accordance with the studies of Pan et al (13) and Laport et al (14), with certain modifications. Peripheral blood was mixed $1: 1(V: V)$ with $0.9 \%$ physiological saline and used for Ficoll density gradient separation (LymphoPrep, PAA, Cölbe, Germany). Following centrifugation at 1,800 rpm for $20 \mathrm{~min}$, the leukocyte layer was collected in fresh tubes. These cells were then washed twice with $0.9 \%$ physiological saline at $1,500 \mathrm{rpm}$ for $7 \mathrm{~min}$. Next, the lymphocyte was cultured in GT-T551 medium (Takara Biotechnology Co., Ltd., Dalian, 
A

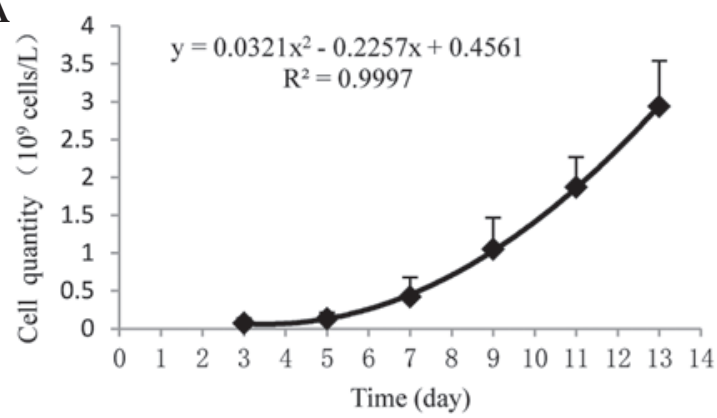

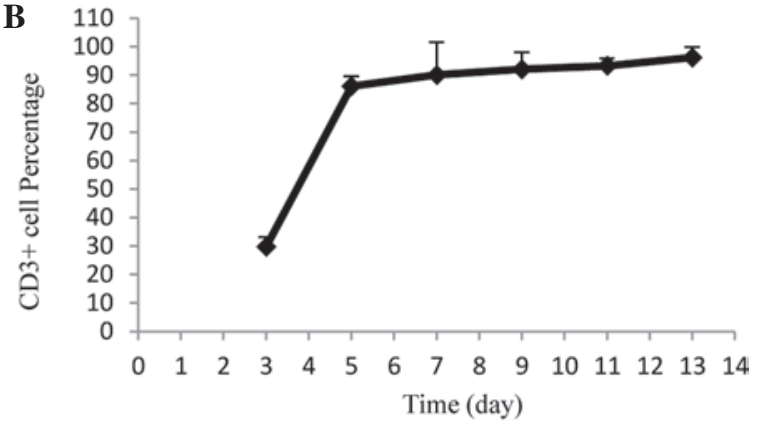

Figure 1. Proliferation activity analysis of cytokine-induced killer cells (CIKs). (A) Change in cell quantity at day 3, 5, 7, 9, 11 and 13 . (B) Expression of CD3 ${ }^{+}$ $\mathrm{T}$ cells in CIKs at day 3, 5, 7,9,11 and 13. Bars represent means \pm standard deviation $(\mathrm{n}=5)$.

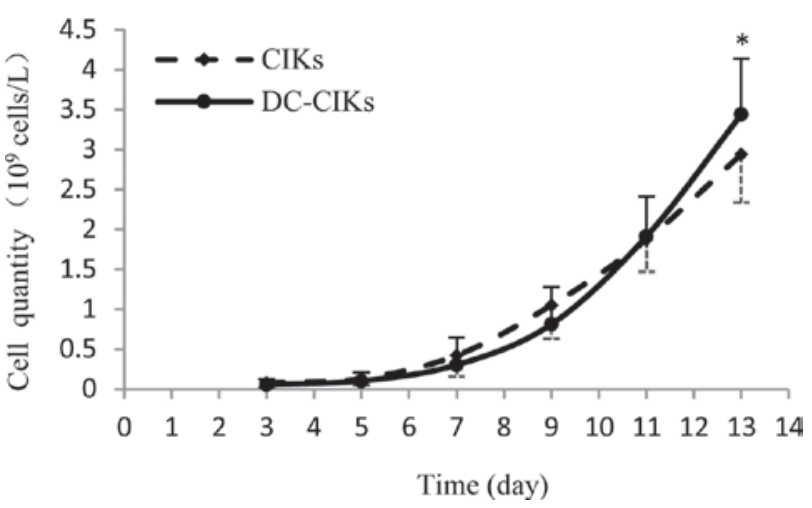

Figure 2. Detection of cell quantity in cytokine-induced killer cells (CIKs) and dendritic cell (DC)-CIKs at various times. Cell quantity was measured at day $3,5,7,9,11$ and 13 , and the DCs were co-cultured with CIKs on day 7. Bars represent means \pm standard deviation $(\mathrm{n}=5) .{ }^{*} \mathrm{P}<0.05$.

China) with 1,000 U/ml $\gamma$-interferon (Beijing Biocoen Biotechnology Co., Ltd., Beijing, China). Ten percent autologous plasma was added on day 0 , then $50 \mu \mathrm{g} / \mathrm{ml} \mathrm{CD} 3$ monoclonal antibody (Skoda Biotechnology Co., Ltd., Beijing, China) and $100 \mathrm{U} / \mathrm{ml}$ interleukin $1 \alpha$ (IL-1 $\alpha$; PeproTech, Suzhou, China) were added on day 1 , and 1,000 U/ml rhIL-2 (SL-PHARM, Beijing, China) and 2\% autologous plasma was included in the medium from day 1 onward with the concentration calculated by a pocH-100i hemtology analyzer (Sysmex, Milton Keynes, UK). The cells were cultured at $37^{\circ} \mathrm{C}$ in $5 \% \mathrm{CO}_{2}$ until day 13 .

DC-CIK culture. The DC cells were cultured in vitro according to the studies of Miao et al and Pan et al with certain modifications $(15,16)$. The lymphocyte separated from the peripheral blood was resuspended with $20 \mathrm{ml}$ GT-T551 medium, and cultured for $3 \mathrm{~h}$ at $37^{\circ} \mathrm{C}$ in $5 \% \mathrm{CO}_{2}$. Finally, the adhered and suspended cells were separated and cultured as mononuclear cells and CIK cells, respectively. The mononuclear cells were cultured with $20 \mathrm{ml}$ AIM-V medium (Invitrogen Life Technologies, Carlsbad, CA, USA) containing $10 \%$ autologous plasma, GM-CSF $(0.2 \mu \mathrm{g} / \mathrm{ml}$, Beijing Biocoen Biotechnology Co., Ltd, Beijing, China) and IL-4 (1 $\mu \mathrm{g} / \mathrm{ml}$, CELLBO Biotechnology Co., Ltd, Wuxi, China). Half of the medium was replaced with fresh medium supplemented with cytokines on day 3 , and TNF- $\alpha(0.2 \mu \mathrm{g} / \mathrm{ml}$, Beijing Biocoen Biotechnology Co., Ltd) was added on day 5 to induce maturation of the DCs. On day 7, the DCs were collected and co-cultured with $\mathrm{CIK}$ at $37^{\circ} \mathrm{C}$ in $5 \% \mathrm{CO}_{2}$ until day 13 .
Flow cytometry analysis. Following culture of CIKs and DC-CIKs for 13 days, $1 \mathrm{ml}$ cell suspension was collected and centrifugated at 1,000 rpm for $10 \mathrm{~min}$, then the precipitate was resuspended in $1 \mathrm{ml} 0.9 \%$ physiological saline, centrifugated at $1,000 \mathrm{rpm}$ for $10 \mathrm{~min}$, then the precipitate was resuspended with $150 \mu 10.9 \%$ physiological saline, and divided into two groups. APC mouse IgG1 $(5 \mu \mathrm{l})$, FITC mouse $\operatorname{IgG} 2 \alpha(5 \mu \mathrm{l})$, PE mouse IgG1 (5 $\mu \mathrm{l})$ and PerCP-CyTM5.5 mouse IgG1 (1 $\mu \mathrm{l})$ were added to one group to form the isotype control, and FITC mouse anti-human CD3 (5 $\mu \mathrm{l})$, PE mouse anti-human CD4 (5 $\mu$ l), PerCP-CyTM5.5 mouse anti-human CD8 (1 $\mu \mathrm{l})$ and APC mouse anti-human CD56 (5 $\mu 1)$ were added to the second group to form the experimental group. The two groups were all incubated for $15 \mathrm{~min}$ at room temperature, then resuspended with $1 \mathrm{ml} 0.9 \%$ physiological saline, and centrifugated at 1,000 rpm for $10 \mathrm{~min}$. Finally, the precipitate was resuspended with $0.2 \mathrm{ml} 0.9 \%$ physiological saline, and prepared for analysis using a BD Accuri C6 flow cytometer (BD Biosciences, Shanghai, China).

Cell viability. Following the culture of CIKs and DC-CIKs for 13 days, $1 \mathrm{ml}$ cell suspension was collected and centrifugated at $1,000 \mathrm{rpm}$ for $10 \mathrm{~min}$, then the precipitate was resuspended in $1 \mathrm{ml} 0.9 \%$ physiological saline and centrifugated at $1,000 \mathrm{rpm}$ for $10 \mathrm{~min}$. Next, the precipitate was resuspended and diluted with physiological saline to $1 \times 10^{5}$ cells $/ \mathrm{ml}$, then the cell suspension was mixed with $0.4 \%$ trypan blue at 9:1 $(V: V)$, and analyzed by Countstar (Inno-Alliance Biotech, Shanghai, China) within 3 min.

3-(4,5-dimethylthiazol-2-yl)-2,5-diphenyltetrazolium bromide (MTT) analysis. Hela cells as target cells were obtained at logarithmic growth phase and the concentration was adjusted to $1 \times 10^{5}$ cells $/ \mathrm{ml}$. CIKs or DC-CIKs cultured for 13 days were used as effector cells, and then mixed with target cells at a proportion of 50:1 (effector cells to target cells). CIK or DC-CIK culture medium $(10 \mathrm{ml})$ was collected, and following centrifugation at $1,000 \mathrm{rpm}$ for $10 \mathrm{~min}$, the precipitate was resuspended with GT-T551 containing $2 \%$ autologous plasma and diluted to $5 \times 10^{6}$ cells $/ \mathrm{ml}$. The cells were divided into three groups: the effector-target group comprised $100 \mu \mathrm{l}$ effector cells and target cells, respectively; the effector cells group comprised $100 \mu$ l effector cells and GT-T551 culture medium; and the target cells group comprised $100 \mu \mathrm{l}$ target cells and GT-T551 culture medium. All groups were cultured at $37^{\circ} \mathrm{C}$ in 
A

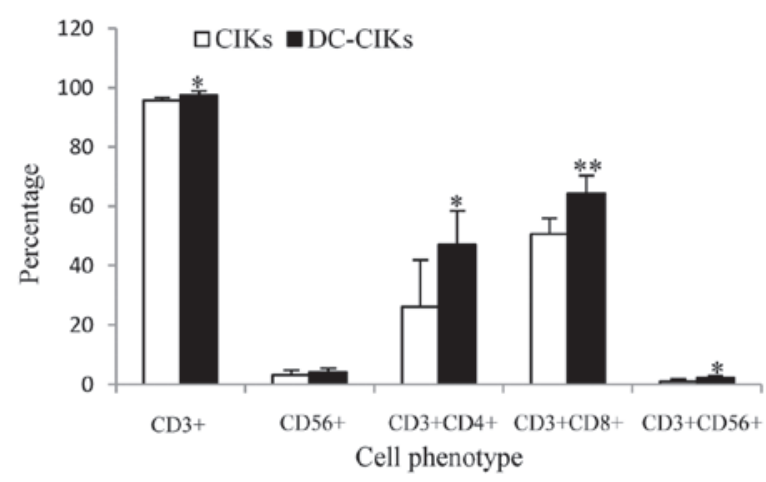

B
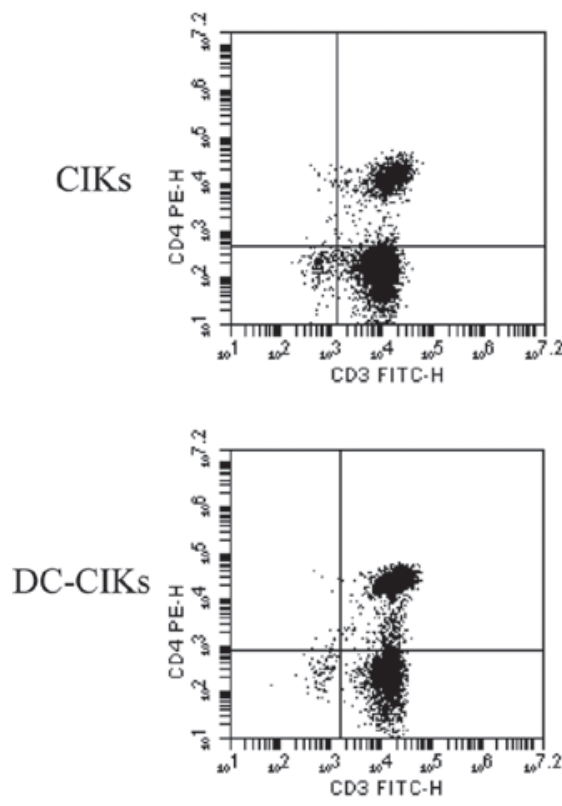

2
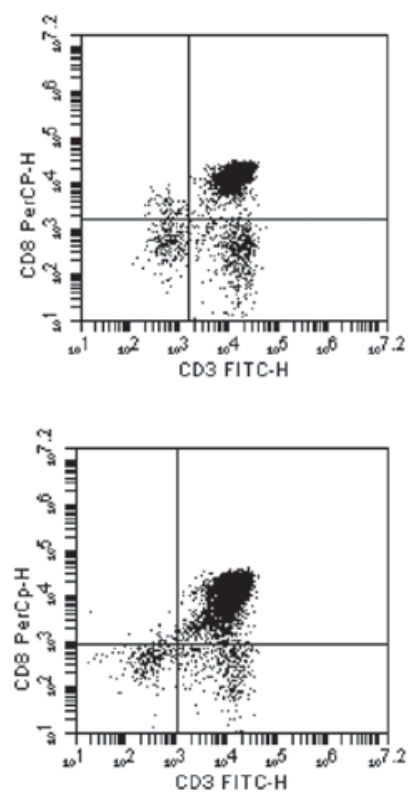

3
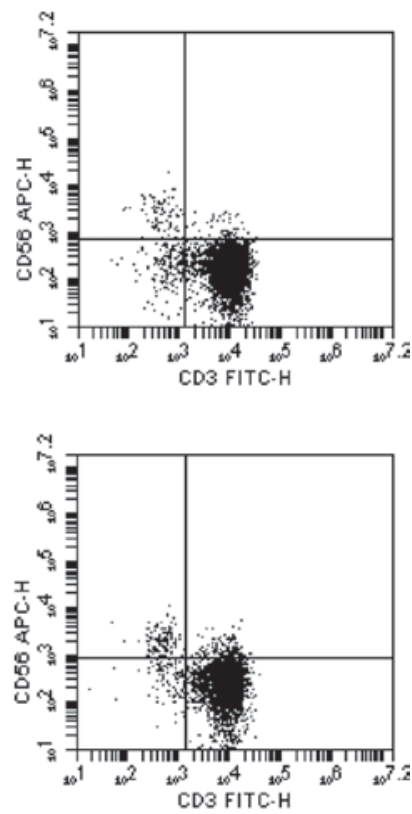

Figure 3. Flow cytometry analysis of the cell phenotype in cytokine-induced killer cells (CIKs) and dendritic cell (DC)-CIKs. (A) Bar graph demonstrating percentage of different cell phenotypes between CIKs and DC-CIKs cultured at day 13. (B) Percentage of different phenotype T cells measured by flow cytometry. Lanes 1-3 represent $\mathrm{CD}^{+}{ }^{+} \mathrm{CD} 4^{+}, \mathrm{CD}^{+} \mathrm{CD}^{+}$and $\mathrm{CD} 3{ }^{+} \mathrm{CD} 56{ }^{+}$phenotype, respectively. Bars represent means \pm standard deviation $(\mathrm{n}=5)$. ${ }^{*} \mathrm{P}<0.05 ;{ }^{* *} \mathrm{P}<0.01$.

$5 \% \mathrm{CO}_{2}$ for $24 \mathrm{~h}$. There were five parallel tubes in every group. Ten microliters MTT $(5 \mathrm{mg} / \mathrm{ml})$ was added and cultured at $37^{\circ} \mathrm{C}$ in $5 \% \mathrm{CO}_{2}$ for $4 \mathrm{~h}$. Following centrifugation at $2,000 \mathrm{rpm}$ for $5 \mathrm{~min}$, the precipitate was dissolved in $100 \mu \mathrm{l}$ dimethyl sulfoxide, agitated for $15 \mathrm{~min}$, and analyzed at an optical density (OD) of $490 \mathrm{~nm}$. The killing rate was calculated as follows:

Rate $=\left[1-\left(O D_{\text {effector-target cell well }}-\mathrm{OD}_{\text {effector cell well }}\right) / \mathrm{OD}_{\text {target cell well }}\right]$ $\mathrm{x} 100 \%$.

\section{Results}

Effect of DCs on CIK cell quantity. To determine the appropriate co-culture time of DCs and CIKs, the cell proliferation of CIKs was analyzed. From day 7, the CIKs were in a period of rapid proliferation (Fig. 1A), and the percentage of $\mathrm{CD}^{+} \mathrm{T}$ cells was over $90 \%$ (Fig. 1B). Of these, DCs were co-cultured with CIKs for 7 days. As shown in Fig. 2, the
DC-CIKs were in rapid proliferation on day 7 , but the cell quantity was lower than that of CIKs until day 11 and the DC-CIK quantity was significantly (1.17-fold) greater than that of CIKs on day 13 .

Difference in cell phenotype between CIKs and DC-CIKs. Next, cell phenotype was analyzed by flow cytometry. As Fig. 3A reveals, the expression of $\mathrm{CD}^{+}, \mathrm{CD}^{+} 6^{+}, \mathrm{CD}^{+} \mathrm{CD} 4^{+}$, $\mathrm{CD}^{+} \mathrm{CD}^{+}$and $\mathrm{CD}^{+}{ }^{+} \mathrm{CD} 56^{+} \mathrm{T}$ cells in $\mathrm{DC}-\mathrm{CIK}$ s was higher than that in $\mathrm{CIKs}$, and the expression of $\mathrm{CD}^{+}, \mathrm{CD}^{+} \mathrm{CD}^{+}$ $\mathrm{CD}^{+}{ }^{+} \mathrm{CD} 8^{+}$and $\mathrm{CD}^{+}{ }^{+} \mathrm{CD} 56^{+} \mathrm{T}$ cells was significantly upregulated $1.02,1.79,1.26$ and 2.44-fold, respectively.

Cell viability and cell cytotoxicity. For further analysis of the influence of DCs on CIKs in vitro, cell viability analysis and MTT were used. The CIK and DC-CIK cell viability was 96 and $98 \%$, respectively (Fig. 4), and there was no significant difference between CIKs and DC-CIKs. In addition, MTT results revealed that the CIK and DC-CIK cell cytotoxicity 

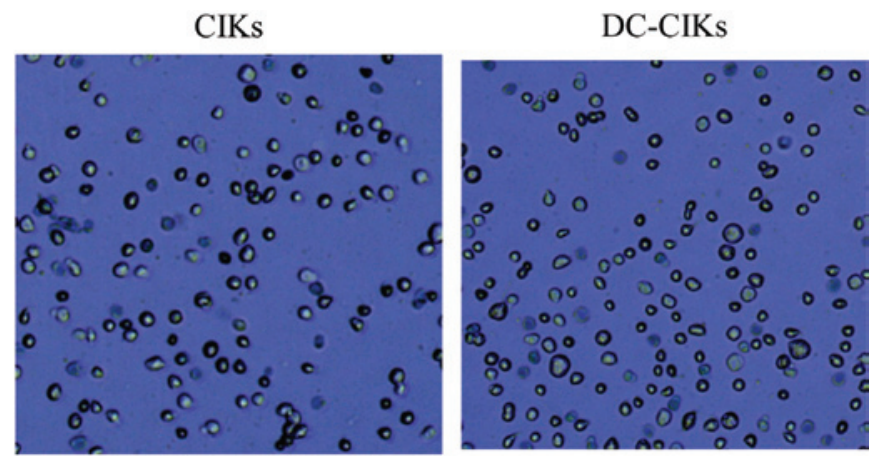

Figure 4. Cell viability analysis. Cells (900 $\mu 1$ cell suspension) were dyed with $100 \mu 10.4 \%$ trypan blue at room temperature for $3 \mathrm{~min}$, then a $10 \mu \mathrm{l}$ sample was analyzed by Countstar. Those with bright color are living cells. CIKs, cytokine-induced killer cells; DC, dendritic cells.

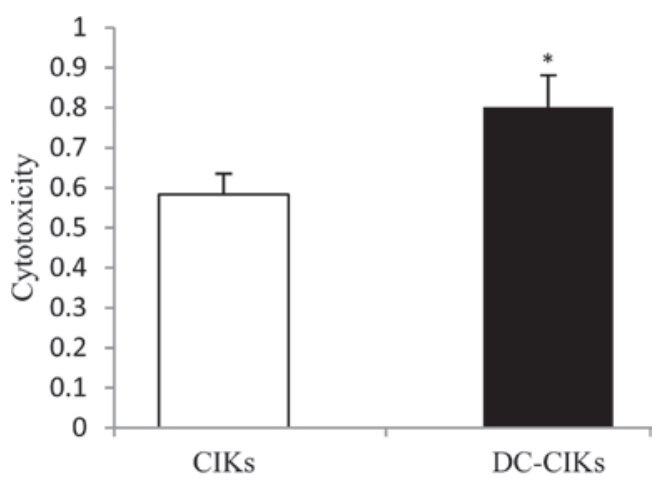

Cell types

Figure 5. 3-(4,5-dimethylthiazol-2-yl)-2,5-diphenyltetrazolium bromide analysis of cytotoxicity of cytokine-induced killer cells (CIKs) and dendritic cell (DC)-CIKs in Hela cells. Bars represent means \pm standard deviation $(\mathrm{n}=5) .{ }^{*} \mathrm{P}<0.05$.

in Hela cells was 58 and $80 \%$, respectively, with a significant difference (Fig. 5).

\section{Discussion}

DCs, known to be the most powerful APCs, play a significant role in immune response regulation, induce primary immune responses, and potentiate the effector functions of previously primed T lymphocytes (17-19). Usually, tumor patients have low immune function, which leads to tumor cells escaping autoimmune response. CIK cells are a subset of natural killer T lymphocytes (NKTs) that are type II NKT cells (20) with enhanced tumor cell lytic activity (21), higher proliferation rate (22), and relatively lower toxicity (23). Due to these characteristics, CIKs are extensively used in antitumor therapy in clinics (24-26).

In this study, the influence of DCs on CIKs was analyzed. The results revealed that DCs were suitable for co-culture with CIKs on day 7 (Fig. 1), and that the cell quantity of DC-CIKs was significantly improved compared with that of CIKs on day 13 (Fig. 2). Notably, the cell proliferation quantity is related to the cytotoxicity of CIKs to tumors $(27,28)$. Therefore, these results strongly suggest that the antitumor activity of DC-CIKs is enhanced compared with that of CIKs.
Furthermore, the difference in cell phenotype between CIKs and DC-CIKs was analyzed by flow cytometry. The results revealed that $\mathrm{CD}^{+}, \mathrm{CD}^{+}{ }^{+} \mathrm{CD} 4^{+}, \mathrm{CD}^{+}{ }^{+} \mathrm{CD} 8^{+}$and $\mathrm{CD}^{+}{ }^{+} \mathrm{CD} 56^{+} \mathrm{T}$ cells were significantly increased $(1.02,1.79$, 1.26 and 2.44-fold, respectively) in DC-CIKs compared with CIKs (Fig. 3). The $\mathrm{CD}^{+}$phenotype is a characteristic of $\mathrm{T}$ cells (29). $\mathrm{CD}^{+} \mathrm{CD}^{+} \mathrm{T}$ cells may induce differentiation into Th1 or Th 2 cells by DCs, which secrete IFN- $\gamma$ or IL-4, IL-10, and IL-13 (18). $\mathrm{CD}^{+} \mathrm{CD}^{+} \mathrm{T}$ cells play an essential role in the immune response against cancers (30). $\mathrm{CD}^{+} \mathrm{CD} 56^{+} \mathrm{T}$ cells are a subset of type II NKT cells with non-major histocompatibility complex-restricted tumor-killing activity $(20,31)$. Collectively, these findings revealed that DC-CIKs were more effective as antitumor agents than CIKs.

To investigate the cytotoxicity of CIKs and DC-CIKs in Hela cells, cell viability analysis and MTT were used. As a result, the DC-CIK and CIK cell viability was $96 \%$ and 98\%, respectively (Fig. 4). MTT revealed that the CIK and DC-CIK cytotoxicity was $58 \%$ and $80 \%$, respectively, with a significant difference (Fig. 5). This is similar to the finding that CIK cytotoxicity was significantly enhanced using the MTT method $(1,32)$. Thus, it may be assumed that DCs are beneficial to the enhancement of CIK cytotoxicity.

In conclusion, this study is likely to be useful in the application of DC-CIKs in antitumor therapy in the clinic. It describes for the first time how DCs co-cultured with CIKs are of benefit for the improvement of the CIK cell proliferation, cell phenotype and antitumor activity in vitro.

\section{Acknowledgements}

The authors would like to thank Dr. Yueling Zhang for revising the English in the manuscript. This study was sponsored by the Special Fund for the Development of Strategic Emerging Industries of Shenzhen City (no. CYZZ20130329145313934).

\section{References}

1. Qu HQ, Zhou XS, Zhou XL and Wang J: Effect of DC-CIK cell on the proliferation, apoptosis and differentiation of leukemia cells. Asian Pac J Trop Med 7: 659-662, 2014.

2. Schmeel FC, Schmeel LC, Gast SM and Schmidt-Wolf IG: Adoptive immunotherapy strategies with cytokine-induced killer (CIK) cells in the treatment of hematological malignancies. Int J Mol Sci 15: 14632-14648, 2014.

3. Wefers C, Lambert LJ, Torensma R and Hato SV: Cellular immunotherapy in ovarian cancer: Targeting the stem of recurrence. Gynecol Oncol 137: 335-342, 2015.

4. Wongkajornsilp A, Wamanuttajinda V, Kasetsinsombat K, Duangsa-ard S, Sa-ngiamsuntorn $K$, Hongeng $S$ and Maneechotesuwan K: Sunitinib indirectly enhanced anti-tumor cytotoxicity of cytokine-induced killer cells and $\mathrm{CD} 3^{+} \mathrm{CD} 56^{+}$subset through the co-culturing dendritic cells. PLoS One 8: e78980, 2013.

5. Introna M, Golay J and Rambaldi A: Cytokine induced killer (CIK) cells for the treatment of haematological neoplasms. Immunol Lett 155: 27-30, 2013.

6. Banchereau J and Palucka AK: Dendritic cells as therapeutic vaccines against cancer. Nat Rev Immunol 5: 296-306, 2005.

7. Thorne SH, Negrin RS and Contag CH: Synergistic antitumor effects of immune cell-viral biotherapy. Science 311: 1780-1784, 2006.

8. Thurner B, Haendle I, Röder C, Dieckmann D, Keikavoussi P, Jonuleit H, Bender A, Maczek C, Schreiner D, von den Driesch P, et al: Vaccination with mage-3A1 peptide-pulsed mature, monocyte-derived dendritic cells expands specific cytotoxic $\mathrm{T}$ cells and induces regression of some metastases in advanced stage IV melanoma. J Exp Med 190: 1669-1678, 1999. 
9. Nestle FO, Alijagic S, Gilliet M, Sun Y, Grabbe S, Dummer R, Burg G and Schadendorf D: Vaccination of melanoma patients with peptide- or tumor lysate-pulsed dendritic cells. Nat Med 4: 328-332, 1998

10. Mody N, Dubey S, Sharma R, Agrawal U and Vyas SP: Dendritic cell-based vaccine research against cancer. Expert Rev Clin Immunol 11: 213-232, 2015.

11. Frank MO, Kaufman J, Parveen S, Blachère NE, Orange DE and Darnell RB: Dendritic cell vaccines containing lymphocytes produce improved immunogenicity in patients with cancer. J Transl Med 12: 338, 2014.

12. Zhu H, Yang X, Li J, Ren Y, Zhang T, Zhang C, Zhang J, Li J and Pang Y: Immune response, safety and survival and quality of life outcomes for advanced colorectal cancer patients treated with dendritic cell vaccine and cytokine-induced killer cell therapy. Biomed Res Int 2014: 603871, 2014.

13. Pan K, Li YQ, Wang W, Xu L, Zhang YJ, Zheng HX, Zhao JJ, Qiu HJ, Weng DS, Li JJ, et al: The efficacy of cytokine-induced killer cell infusion as an adjuvant therapy for postoperative hepatocellular carcinoma patients. Ann Surg Oncol 20: 4305-4311, 2013.

14. Laport GG, Sheehan K, Baker J, Armstrong R, Wong RM, Lowsky R, Johnston LJ, Shizuru JA, Miklos D, Arai S, et al: Adoptive immunotherapy with cytokine-induced killer cells for patients with relapsed hematologic malignancies after allogeneic hematopoietic cell transplantation. Biol Blood Marrow Transplant 17: 1679-1687, 2011.

15. Miao L, Run-Ming J and Yi J: T-Bet mediated anti-neoplastic effects of dendritic cell-cytokine induced killer cells in vitro. Iran J Pediatr 22: 43-51, 2012.

16. Pan Y, Tao Q, Wang H, Xiong S, Zhang R, Chen T, Tao L and Zhai Z: Dendritic cells decreased the concomitant expanded Tregs and Tregs related IL-35 in cytokine-induced killer cells and increased their cytotoxicity against leukemia cells. PLoS One 9: e93591, 2014.

17. Lenahan C and Avigan D: Dendritic cell defects in patients with cancer: mechanisms and significance. Breast Cancer Res 8: 101, 2006.

18. Chen J, Wei Y, He J, Cui G, Zhu Y, Lu C, Ding Y, Xue R, Bai L, Uede T, et al: Natural killer $\mathrm{T}$ cells play a necessary role in modulating of immune-mediated liver injury by gut microbiota. Sci Rep 4: 7259, 2014.

19. Datta J, Terhune JH, Lowenfeld L, Cintolo JA, Xu S, Roses RE and Czerniecki BJ: Optimizing dendritic cell-based approaches for cancer immunotherapy. Yale J Biol Med 87: 491-518, 2014.

20. Gütgemann S, Frank S, Strehl J and Schmidt-Wolf IG: Cytokine-induced killer cells are type II natural killer T cells. Ger Med Sci 5: Doc07, 2007.
21. Margolin KA, Negrin RS, Wong KK, Chatterjee S, Wright C and Forman SJ: Cellular immunotherapy and autologous transplantation for hematologic malignancy. Immunol Rev 157: 231-240, 1997.

22. Linn YC and Hui KM: Cytokine-induced killer cells: NK-like $\mathrm{T}$ cells with cytotolytic specificity against leukemia. Leuk Lymphoma 44: 1457-1462, 2003.

23. Hontscha C, Borck Y, Zhou H, Messmer D and Schmidt-Wolf IG: Clinical trials on CIK cells: first report of the international registry on CIK cells (IRCC). J Cancer Res Clin Oncol 137: 305-310, 2011.

24. Jäkel CE, Vogt A, Gonzalez-Carmona MA and Schmidt-Wolf IG: Clinical studies applying cytokine-induced killer cells for the treatment of gastrointestinal tumors. J Immunol Res 2014: 897214, 2014.

25. Zhang Y, Xia L, Zhang Y, Wang Y, Lu X, Shi F, Liu Y, Chen M, Feng $\mathrm{K}$, Zhang W, et al: Analysis of adverse events following the treatment of autologous cytokine-induced killer cells for adoptive immunotherapy in malignant tumour sufferers. Expert Opin Biol Ther 15: 481-493, 2015.

26. Zhang Q, Liu XY, Zhang T, Zhang XF, Zhao L, Long F Liu ZK and Wang EH: The dual-functional capability of cytokine-induced killer cells and application in tumor immunology. Hum Immunol 76: 385-391, 2015.

27. Bach M, Schimmelpfennig C and Stolzing A: Influence of murine mesenchymal stem cells on proliferation, phenotype, vitality, and cytotoxicity of murine cytokine-induced killer cells in coculture. PLoS One 9: e88115, 2014.

28. Chan WC and Linn YC: A comparison between cytokine- and bead-stimulated polyclonal T cells: the superiority of each and their possible complementary role. Cytotechnology: Dec 7, 2014 (Epub ahead of print)

29. Wang M, Cao JX, Pan JH, Liu YS, Xu BL, Li D, Zhang XY, Li JL, Liu JL, Wang HB and Wang ZX: Adoptive immunotherapy of cytokine-induced killer cell therapy in the treatment of non-small cell lung cancer. PLoS One 9: el12662, 2014.

30. Salaun B, Yamamoto T, Badran B, Tsunetsugu-Yokota Y, Roux A, Baitsch L, Rouas R, Fayyad-Kazan H, Baumgaertner P, Devevre $\mathrm{E}$, et al: Differentiation associated regulation of microRNA expression in vivo in human $\mathrm{CD}^{+} \mathrm{T}$ cell subsets. J Transl Med 9: 44, 2011.

31. Schmeel LC, Schmeel FC, Coch C and Schmidt-Wolf IG: Cytokine-induced killer (CIK) cells in cancer immunotherapy: report of the international registry on CIK cells (IRCC). J Cancer Res Clin Oncol 141: 839-849, 2015.

32. Xue CM, Chen $\mathrm{C}$, Xu J, et al: Influence of some traditional Chinese medicines (TCMS) on cytokine-induced killer cells proliferation and anti-tumor features in vitro. Int J Res Ayurveda Pharm 4: 228-232, 2013. 